Check for updates

Cite this: RSC Adv., 2019, 9, 29195

\title{
The structural diversity of heterocycle-fused potassium cyclopentadienides $\uparrow$
}

\author{
Ilya E. Nifant'ev, (D) *ab Alexander A. Vinogradov, ${ }^{a}$ Mikhail E. Minyaev, ${ }^{a}$ \\ Pavel D. Komarov, ${ }^{a}$ Konstantin A. Lyssenko, (D) bc Kirill P. Birin, (DD d \\ Viktor P. Dyadchenko ${ }^{b}$ and Pavel V. Ivchenko (D) ab
}

Cyclopentadienides of $d$ - and f-elements are highly important complexes with undoubted potential for practical applications. Annelation of a heterocyclic fragment with an $\eta^{5}$-ring results in substantial improvement of the catalytic properties of these compounds, called "heterocenes"; the investigation of metal coordination with these specific ligands is a highly important problem. We prepared potassium derivatives 5-8 of heterocycle-annelated cyclopentadienes with different structures - derivatives of cyclopenta[1,2-b:4,3- $\left.b^{\prime}\right]$ dithiophene (1), indeno[2,1-b]indole (2), indeno[1,2-b]indole (3), and indeno[1,2b]indolizine (4) and studied the crystal and molecular structures of these salts by X-ray diffraction. We found that heterocycle-fused cyclopentadienides demonstrate remarkable diversity in metal-ligand coordination modes and crystal packing, with formation of two-dimensional polymeric (5), linear polymeric (6), tetrameric (7) and monomeric (8) structures. The NMR spectral data and results of DFT modeling indicate an increase in electron density in the cyclopentadienyl fragment, and this effect was found to be larger in the derivative of the new indolizine ligand precursor 4 . The results of our study will be used in the design of next-generation catalysts of $\alpha$-olefin polymerization.

Received 18th June 2019

Accepted 6th September 2019

DOI: $10.1039 / \mathrm{c} 9 \mathrm{ra} 04587 \mathrm{~b}$

rsc.li/rsc-advances ligands have been successfully applied in the design of an effective epoxidation catalyst; 9 sandwich and half-sandwich complexes of group 4 metals (so-called "heterocenes") represent next-generation metallocene catalysts for $\alpha$-olefin polymerization. ${ }^{\mathbf{1 0}-15}$

Recently, we demonstrated the high efficiency of cyclopenta[ $b]$ thiophene $\mathrm{Zr}$ complexes in oligomerization of $\mathrm{C}_{6}-\mathrm{C}_{10} \alpha$-olefins, ${ }^{16}$ and the promising catalytic properties of $\mathrm{Zr}$ ansa-complexes based on cyclopenta[1,2-b:4,3- $\left.b^{\prime}\right]$ dithiophene, indeno[1,2-b] indole and indeno[2,1-b]indole (Scheme 2, top) in polymerization of 1-octene. ${ }^{17}$ In our experiments, heterocenes outperformed traditional cyclopentadienyl, indenyl and fluorenyl sandwich carbon ring with a heterocyclic fragment is a promising direction in the design of the heteroanalogs of indene and fluorene (Scheme 1) which represent prospective $\eta^{5}$-ligands. Such

${ }^{a}$ A. V. Topchiev Institute of Petrochemical Synthesis, Russian Academy of Sciences, Leninsky Pr. 29, Moscow 119991, Russian Federation. E-mail: ilnif@yahoo.com

${ }^{b}$ Chemistry Department, M. V. Lomonosov Moscow State University, Leninskie Gory, 13, Moscow 119991, Russian Federation

'Plekhanov Russian University of Economics, Stremyanny Per. 36, Moscow 117997, Russian Federation

${ }^{d}$ A. N. Frumkin Institute of Physical Chemistry and Electrochemistry, Russian Academy of Sciences, Leninsky Pr. 31, Moscow 119071, Russian Federation

$\dagger$ Electronic supplementary information (ESI) available: Synthesis of 1-3, NMR spectra of 4-8, details of X-ray diffraction study of 5-8, results of DFT calculations (table of charges and common .xyz file). CCDC 1920202-1920205. For ESI and crystallographic data in CIF or other electronic format see DOI: 10.1039/c9ra04587b

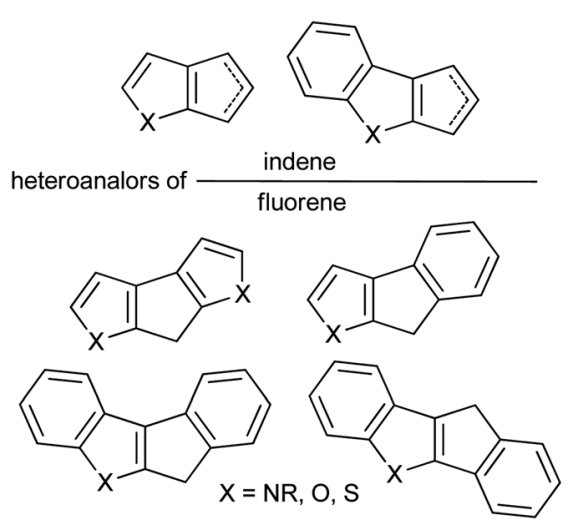

Scheme 1 Donor heterocycle - fused cyclopentadienes. 
complexes. This behavior indicates that heterocene ligands much more effectively stabilize the $\mathrm{Zr}$ cationic reaction center relative to traditional cyclopentadienides due to their electron-donor nature ${ }^{18}$ which entails increasing in catalytic activity and feasibility of using heterocenes at elevated temperatures. The structural diversity of heterocycle-fused cyclopentadienes permits a more variety in stereocontrol of $\alpha$-olefin insertion: rac-forms of ansa-zirconocenes based on heteroanalogs of indene allows to obtain isotactic polypropylene ${ }^{\mathbf{1 9}}$ or polypropylene elastomers; ${ }^{\mathbf{2 0}, 21}$ Zr complexes based on heteroanalogs of fluorene were successfully used in the synthesis of polypropylene elastomers, ${ }^{11,14,15}$ isotactic poly(1-butene), ${ }^{12}$ high $\mathrm{MW}$ atactic polyolefins ${ }^{17}$ and other prospective materials.

Heterocenes have been extensively studied in $\alpha$-olefin polymerization since the early 2000s. The molecular structure of these compounds is poorly studied; to date, only a few dichlorozirconium ansa-complexes have been characterized by X-ray diffraction analysis. ${ }^{\mathbf{1 0 , 1 7 , 1 9 - 2 4}}$ Obviously, these data do not reflect the entire spectrum of possible metal-ligand interactions in catalytic species due to the predominantly covalent nature of bonding in neutral $\mathrm{LZCCl}_{2}$ complexes.
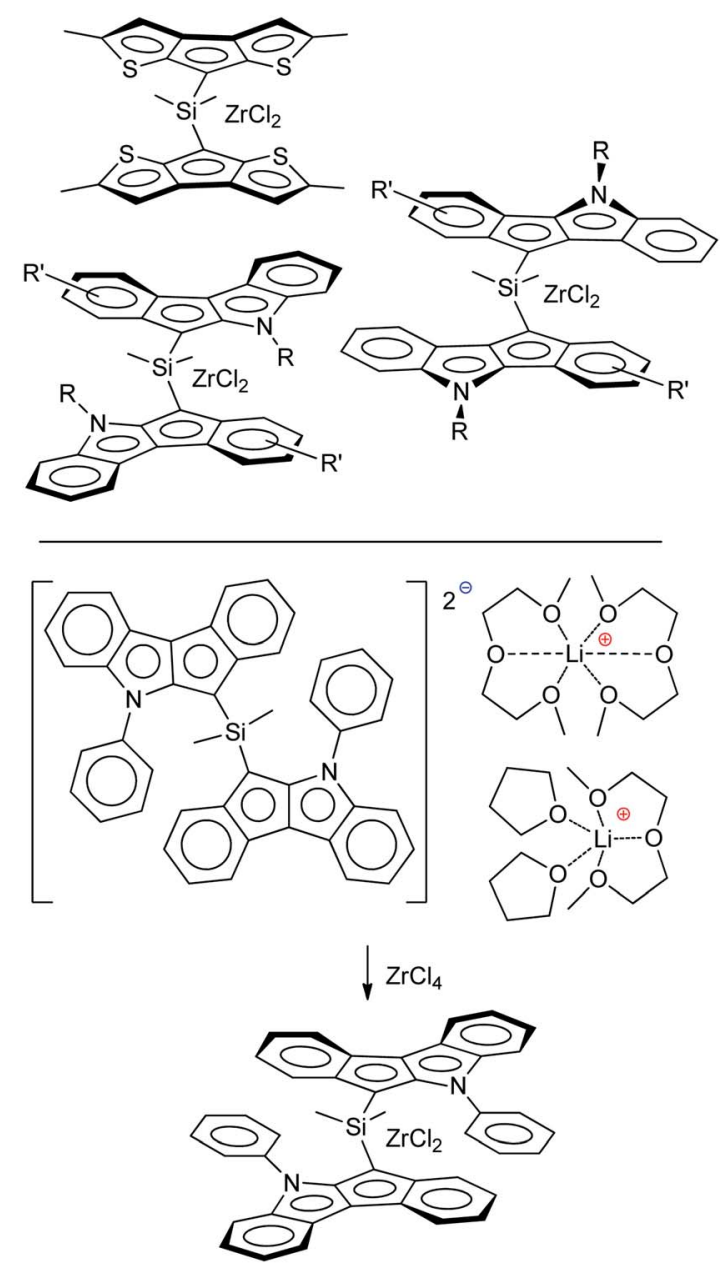

Scheme 2 Heterocenes - promising precatalysts for $\alpha$-olefin polymerization (top); racemo-selective transmetallation of dilithium salt (bottom). ${ }^{25}$
We believe that a detailed study of the molecular structure of alkali metal derivatives of heterocycle-fused cyclopentadienes is an effective tool to find such interactions. These studies also have an important practical aspect, since the structure of alkali metal cyclopentadienides is crucially important for the transmetallation that is used in the synthesis of metallocenes; recently, we detected high racemo-selectivity in the synthesis of zirconium complex (Scheme 2, bottom), and this selectivity could be attributed to effects of crystal packing in the corresponding dilithium salt. ${ }^{25}$

On the other hand, heterocycle-fused cyclopentadienides may be considered as a "bridge" between traditional derivatives of alkyl- or aryl-substituted cyclopentadiene, indene, and fluorene $^{26}$ - and side-chain functionalized cyclopentadienides ${ }^{27}-$ thus complementing and completing our knowledge of the nature of alkali metal $\pi$-ligand coordination.

In this paper, we report the synthesis and crystallographic study of four heterocene-fused potassium cyclopentadienides.

\section{Results and discussion}

\section{The synthesis of heterocycle-fused cyclopentadienes}

2,5-Dimethyl-7 $H$-cyclopenta[1,2- $\left.b: 4,3-b^{\prime}\right]$ dithiophene $\quad \mathbf{1 , 1 4 , 2 8}^{\mathbf{1 4}} \quad 5$ methyl-5,6-dihydroindeno[2,1-b]indole 2 (ref. 29) and 5-methyl5,10-dihydroindeno[1,2-b]indole 3 (ref. 30) were synthesized according to previously reported procedures (see also ${ }^{17}$ and Section $\mathrm{S} 1$ in the ESI $\dagger$ ). 11-Phenyl- $6 H$-indeno[1,2- $b]$ indolizine 4 is a new compound that was prepared by Scheme 3 (see Section $\mathrm{S} 1$ in the ESI $\dagger$ for NMR spectra). The synthesis of 4 was based on the quaternization of 2-benzylpyridine with 2-bromo-2,3-dihydro- $1 H$-inden-1-one ${ }^{31}$ followed by cyclization in basic aqueous media. ${ }^{32}$ Note that 4 is the first example of a cyclopentadienyltype ligand precursor with indolizine fragment.

\section{Preparation and NMR study of potassium salts}

Potassium salts were obtained from corresponding heterocyclefused cyclopentadienes 1-4 by metallation with benzyl potassium in THF medium. This efficient method of metallation of

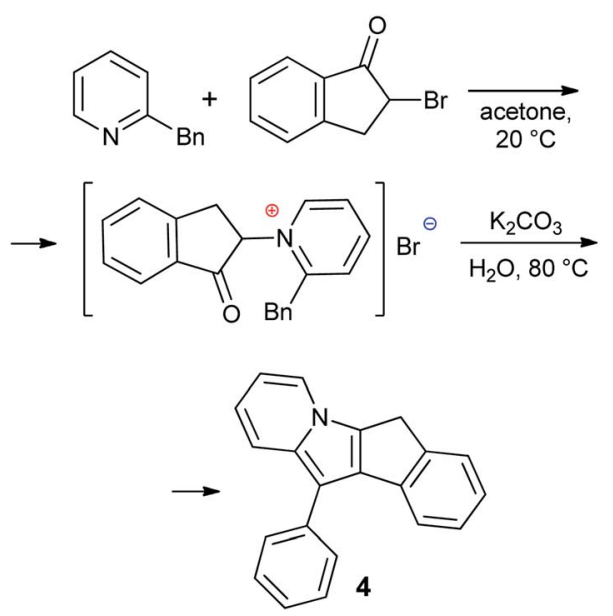

Scheme 3 Synthesis of 11-phenyl-6H-indeno[1,2-b]indolizine (4). 
substituted cyclopentadienes, which we recently proposed, ${ }^{33-35}$ significantly increased the availability of potassium derivatives that are synthetic precursors of cyclopentadienyl complexes. Crystalline salts 5-8 were obtained by slow ( $\sim 1$ week) diffusion of $n$-hexane into solutions of metallation products in THF (5) or in THF/diglyme mixture (for $\mathbf{6 - 8}$, see Scheme 4). The crystals obtained were suitable for X-ray diffraction analysis.

Using correlation NMR techniques, we accomplished complete signal assignment in ${ }^{1} \mathrm{H}$ and ${ }^{13} \mathrm{C}$ NMR spectra of 5-8 (see Section S1 in the ESI†). We conclude that the values of ${ }^{13} \mathrm{C}$ NMR chemical shifts related to $\mathrm{C}(\mathrm{H})$ carbon atom correlate to electron density in the $\mathrm{C}_{5}$ fragment of the cyclopentadienide anion. In comparison with such values in cyclopentadienides and fluorenides, the chemical shifts for heterocycle-fused cyclopentadienides 5-8 are substantially lower (Table 1 ). The degree of shielding is minimal for $\mathbf{5}$ and maximal for indolizine derivative 8, which correlates with results of DFT calculations.

\section{Crystallographic study of potassium salts}

Potassium derivatives of heterocycle-fused cyclopentadienes demonstrated a remarkable versatility in metal coordination and crystal packing (Scheme 4).

Potassium 2,5-dimethyl-7H-cyclopenta[1,2-b:4,3- $\left.b^{\prime}\right]$ dithiophenide 5. The complex $\left[\mathrm{K}(\mathrm{THF})\left(\mathrm{Me}_{2} \mathrm{C}_{9} \mathrm{H}_{3} \mathrm{~S}_{2}\right)\right]_{\infty}$ (5) contains two $\mathrm{K}^{+}$cations connected via two bridging THF molecules, forming a dimeric dication $\left[\mathrm{K}_{2}(\mu-\mathrm{THF})_{2}\right]^{2+}$. Each $\mathrm{K}^{+}$is coordinated by two symmetrically nonequivalent nearly flat 2,5-dimethyl- $7 \mathrm{H}$-cyclopenta[1,2-b:4,3- $\left.b^{\prime}\right]$ dithiophenide anions (Fig. 1, for the asymmetric unit see Fig. S27 in the ESI $\dagger$ ). Bond distances within the anions of $\mathbf{1}$ are presented on Scheme 5 and in Table 2. The $\mathrm{C}-\mathrm{C}$ bond lengths within the central $\mathrm{C}_{5}$-rings are similar and have
Table 1 Chemical shifts $(\delta, \mathrm{ppm})$ of $\mathrm{C}(\mathrm{H})$ atoms of $\mathrm{C}_{5}$ fragments in ${ }^{1} \mathrm{H}$ and ${ }^{13} \mathrm{C}$ NMR spectra of cyclopentadienides (THF- $\mathrm{d}_{8}$ )

\begin{tabular}{llll}
\hline Cyclopentadienide & ${ }^{1} \mathrm{H}$ NMR, $\mathrm{H}_{\mathrm{Cp}}$ & ${ }^{13} \mathrm{C} N \mathrm{NMR}, \mathrm{C}(\mathrm{H})_{\mathrm{Cp}}$ & Reference \\
\hline $\mathbf{5}$ & 5.64 & 82.4 & $a$ \\
$\mathbf{6}$ & 5.51 & 69.3 & $a$ \\
7 & 5.92 & 75.9 & $a$ \\
$\mathbf{8}$ & 5.88 & 67.6 & $a$ \\
$\left(\mathrm{C}_{5} \mathrm{H}_{5}\right) \mathrm{Na}$ & 5.60 & 103.3 & 36 \\
$\left(\mathrm{C}_{5} \mathrm{H}_{5}\right) \mathrm{K}$ & 5.57 & 102.1 & 37 \\
$\left({ }^{5} \mathrm{BuC}_{5} \mathrm{H}_{4}\right) \mathrm{K}$ & $5.36,5.42$ & $104.1,103.8$ & 37 \\
$\left({ }^{t} \mathrm{Bu}_{3} \mathrm{C}_{5} \mathrm{H}_{2}\right) \mathrm{K}$ & 5.56 & 101.5 & 37 \\
$\left(\mathrm{C}_{9} \mathrm{H}_{7}\right) \mathrm{Li}^{b}$ & $6.51,5.89$ & $116.6,92.7$ & 38 \\
$\left(\mathrm{C}_{13} \mathrm{H}_{9}\right) \mathrm{K}^{c}$ & 6.93 & 84.1 & 39 \\
$\left(\mathrm{C}_{13} \mathrm{H}_{9}\right) \mathrm{K}(\text { diglyme })^{c}$ & 6.04 & 83.0 & 40
\end{tabular}

${ }^{a}$ This work. ${ }^{b} \mathrm{C}_{9} \mathrm{H}_{7}=$ indenide. ${ }^{c} \mathrm{C}_{13} \mathrm{H}_{9}=$ fluorenide.

average values of 1.420(6) $\mathrm{A}$ for $\mathrm{C} 1 \cdots \mathrm{C} 5$ and $1.423(6) \AA$ for $\mathrm{C} 12 \cdots$ C16.

Interactions of $\mathrm{K}^{+}$cations with the ligand via its middle ring are symmetrical in cases of $\mathrm{K} 1-\mathrm{C} 12^{\mathrm{i}} \cdots \mathrm{C} 16^{\mathrm{i}}$ and $\mathrm{K} 2-\mathrm{C} 1^{\mathrm{ii}} \cdots \mathrm{C} 5^{\mathrm{ii}}$ interactions [symmetry codes: (i) $-x+1, y-1 / 2,-z+1$; (ii) $x+1$, $y, z]$, which is confirmed by very similar values of $\mathrm{K}^{+}$centroid $\left(\mathrm{C}_{5}\right)$ distances and normals from $\mathrm{K}^{+}$to the ligand planes (Table 2). In the case of less symmetrical K1-C1 $\cdots \mathrm{C} 5$ interaction, the difference between the mentioned distances $(\sim 0.078$ $\AA$ ) is explained by the fact that the intersection point of the normal and the $\mathrm{C}_{5}$-plane is shifted from the $\mathrm{C}_{5}$-centroid towards atom $\mathrm{C} 2$, which is likely due to the presence of a relatively long K1-S2 contact (Fig. 1 and S27 in the ESI $\dagger$ ). Moreover, the interaction $\mathrm{K} 2-\mathrm{C} 12 \cdots \mathrm{C} 16$ is far from symmetrical, since cation

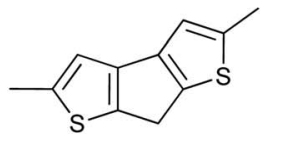

1
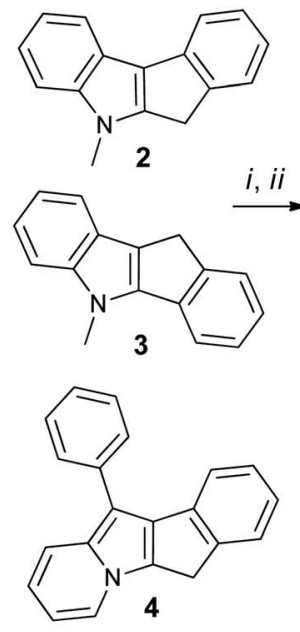
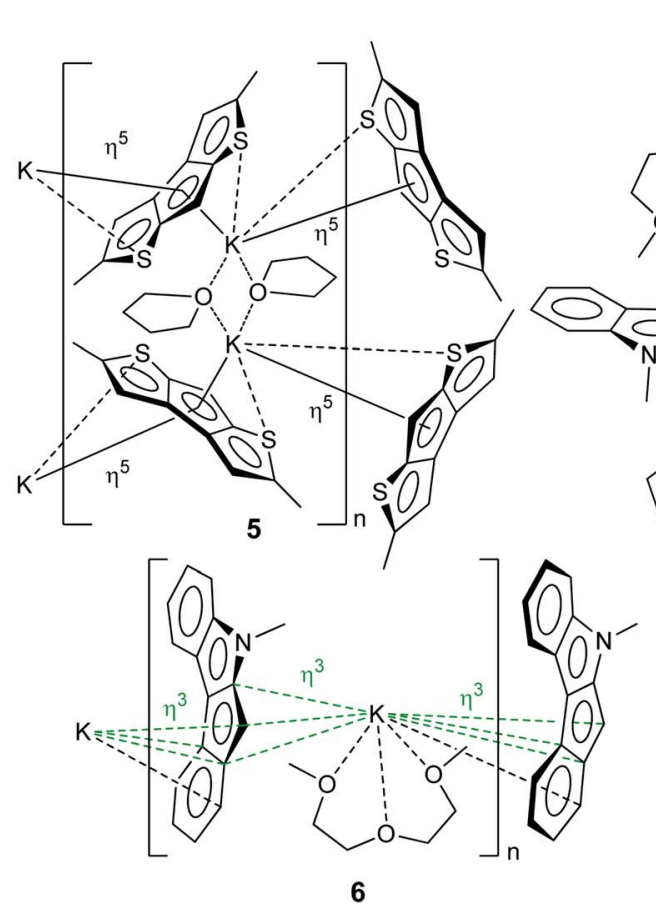

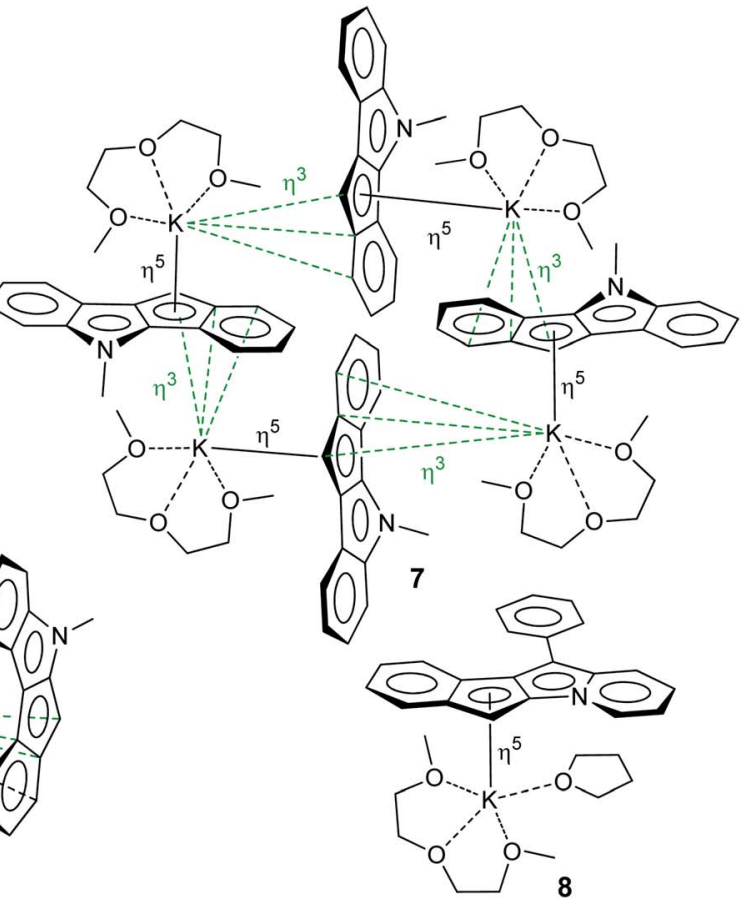

Scheme 4 Preparation of 5-8. (i) BnK/THF; (ii) hexane (5) or hexane/diglyme (6-8). 
$\mathrm{K} 2$ is also coordinated by $\mathrm{C} 19$ and S4 atoms. The normal from $\mathrm{K} 2$ to the $\mathrm{C} 12 \cdots \mathrm{C} 16$ plane intersects the plane close to the middle of the C14-C15 bond and the position of the centroid defined by atoms C13 $\cdots \mathrm{C} 16, \mathrm{C} 19$ and $\mathrm{S} 4$.

Therefore, the anionic ligand displays two similar coordination modes: $\mu-\eta^{5}: \eta^{6}(\mathrm{C} 1 \cdots \mathrm{C} 11, \mathrm{~S} 1, \mathrm{~S} 2)$ and $\mu-\eta^{5}: \eta^{7}(\mathrm{C} 12 \cdots \mathrm{C} 22$, S3, S4). The $\left[\mathrm{K}_{2}(\mu-\mathrm{THF})_{2}\right]^{2+}$ moiety exhibits bonds with four [2,5$\left.\mathrm{Me}_{2} \mathrm{C}_{9} \mathrm{H}_{3} \mathrm{~S}_{2}\right]^{-}$anions, thus forming a $2 \mathrm{D}$ coordination polymer (Fig. 2, S29 and S30 in the ESI $\dagger$ ).

All $\mathrm{K}^{+}$cations lie nearly in one plane in the $2 \mathrm{D}$ sheet with the $\mathrm{K}-\mathrm{K}-\mathrm{K}$ angles ranging from $99.74(1)^{\circ}$ to $139.35(1)^{\circ}$ (Table S2 in the ESI $\dagger$ ). A simplified scheme of Coulomb interactions between dications $\left[\mathrm{K}_{2}(\mathrm{THF})_{2}\right]^{2+}$ and anions $\left[\mathrm{Me}_{2} \mathrm{C}_{9} \mathrm{H}_{3} \mathrm{~S}_{2}\right]^{-}$ within the 2D layer is presented in Fig. S31 in the ESI. $\dagger$

Potassium salts bearing isomeric dihydroindenoindolide anions. The asymmetric unit of colorless salt $\left[\mathrm{K}\right.$ (diglyme) $\left(\mathrm{C}_{16^{-}}\right.$ $\left.\left.\mathrm{H}_{12} \mathrm{~N}\right)\right] 6$ containing 5-methyl-5,6-dihydroindeno[2,1- $\left.b\right]$ indolide/ yl ligand comprises one anion $\left[\mu-\eta^{3}: \eta^{3}-\mathrm{C}_{16} \mathrm{H}_{12} \mathrm{~N}\right]^{-}$and one $\left[\mathrm{K}\left(\text { diglyme- } \kappa \mathrm{O}, \mathrm{O}^{\prime}, \mathrm{O}^{\prime \prime}\right)\right]^{+}$cation (Fig. S32 in the ESI $\dagger$ ). The $\mathrm{K}^{+}$ cation is $\eta^{3}$-coordinated by two nearly flat indenoindolide anions (atoms $\mathrm{C} 2, \mathrm{C} 6, \mathrm{C} 7$ and $\mathrm{C} 6^{\mathrm{i}}, \mathrm{C} 7^{\mathrm{i}}, \mathrm{C} 8^{\mathrm{i}}$; symmetry code: (i) $x$, $-y+1 / 2, z+1 / 2$; see Table 3 for $\mathrm{K}-\mathrm{C}$ bond distances), but their coordination modes are different (Fig. 3). Normals from K1 cation to the ligand planes intersect the planes close to positions of centroids defined by atoms C2, C6, C7 and $\mathrm{C6}^{\mathrm{i}}, \mathrm{C} 7^{\mathrm{i}}, \mathrm{C} 8^{\mathrm{i}}$ (Table 3). Corresponding K-centroid distances have very close values to those of the normals. The second anion additionally exhibits a rather long $\mathrm{K} 1-\mathrm{C} 12^{\mathrm{i}}$ contact. More or less equal charge redistribution within the anion is supported by the values of $\mathrm{C}-\mathrm{N}$ and $\mathrm{C}-\mathrm{C}$ distances (Scheme 5 and Table $\mathrm{S} 3$ in the ESI $\dagger$ ) with the exception of a noticeably longer C7-C8 bond of 1.4651(17) $\AA$, which connects $\mathrm{C}_{5}$ and $\mathrm{C}_{6}$ rings.

The mentioned interionic interactions between the $[\mathrm{K}(\text { diglyme })]^{+}$and $\left[\mu-\eta^{3}: \eta^{3}-\mathrm{C}_{16} \mathrm{H}_{12} \mathrm{~N}\right]^{-}$moieties provide formation of a $1 \mathrm{D}$ coordination polymer structure $\left[\mathrm{K}\right.$ (diglyme) $\left(\mathrm{C}_{16^{-}}\right.$ $\left.\left.\mathrm{H}_{12} \mathrm{~N}\right)\right]_{\infty}$, a part of which is shown in Fig. 3, with the $\mathrm{K} 1^{\mathrm{i}}-\mathrm{K} 1-\mathrm{K} 1^{\mathrm{ii}}$ angle of $127.65(1)^{\circ}$ [symmetry code: (ii) $x,-y+1 / 2, z-1 / 2$ ]. The formed polymer chains are aligned along the $c$ axis (Fig. 3 ).

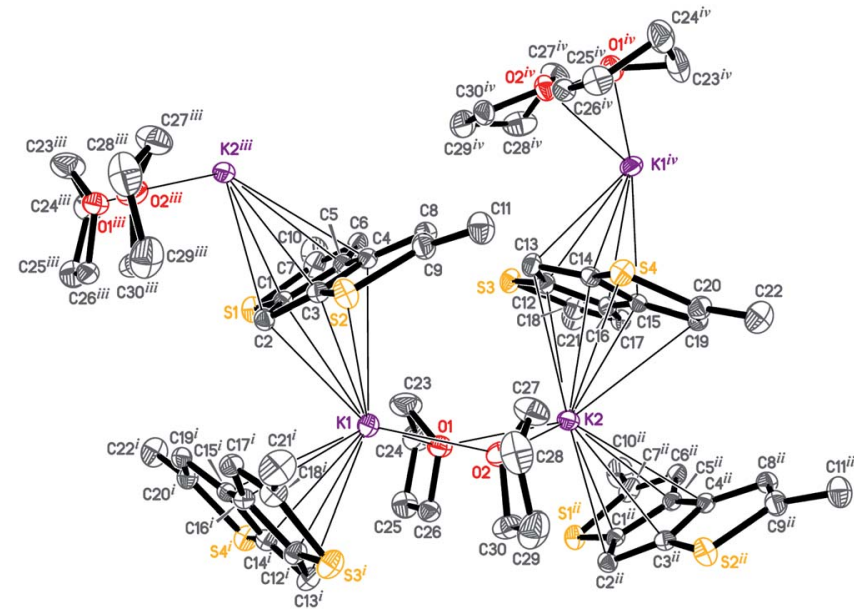

Fig. 1 The structure of $\left[\mathrm{K}_{2}(\mathrm{THF})_{2}\left(\mathrm{Me}_{2} \mathrm{C}_{9} \mathrm{H}_{3} \mathrm{~S}_{2}\right)_{2}\right]_{\infty}$ (5). Displacement ellipsoids are drawn at the $50 \%$ probability level. All $\mathrm{H}$ atoms are omitted, and THF disorder is not shown for clarity.
The isomeric red crystalline complex [K(diglyme) $\left.\left(\mathrm{C}_{16} \mathrm{H}_{12} \mathrm{~N}\right)\right]$ (7) based on 5-methyl-5,10-dihydroindeno[1,2- $b]$ indole has a similar asymmetric unit that includes one cation [K(diglyme$\left.\left.\kappa \mathrm{O}, \mathrm{O}^{\prime}, \mathrm{O}^{\prime \prime}\right)\right]^{+}$and one anion $\left[\mu-\eta^{3}: \eta^{5}-\mathrm{C}_{16} \mathrm{H}_{12} \mathrm{~N}\right]^{-}$(Fig. S36 in the $\mathrm{ESI} \dagger$ ). The $\mathrm{C}-\mathrm{C}$ and $\mathrm{C}-\mathrm{N}$ bond distances in the anion are given in Scheme 5 and in Table $\mathrm{S} 4$ (ESI $\dagger$ ). These values are expected, but the C7-C8 bond (1.4711(19) $\AA$ ) that is common to $\mathrm{C}_{5}$ and $\mathrm{C}_{6}$ rings is elongated as in complex 6. Atom $\mathrm{K} 1$ is $\eta^{5}$-coordinated by one ligand (atoms $\mathrm{C} 4-\mathrm{C} 8$ ) and $\eta^{3}$-coordinated by the other ligand (atoms $\mathrm{C}^{\mathrm{i}}, \mathrm{C}^{\mathrm{i}}$ and $\mathrm{C} 12^{\mathrm{i}}$ ) as shown in Fig. 4 [symmetry code: (i) $y,-x+3 / 2,-z+1 / 2]$. The normal from $\mathrm{K} 1$ to the plane defined by atoms N1, C2-C17 is 2.9430(5) $\AA$, which is close to

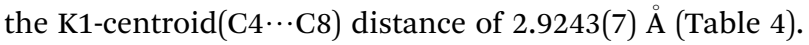

The $\left[\mathrm{K}(\right.$ diglyme $\left.)\left(\mathrm{C}_{16} \mathrm{H}_{12} \mathrm{~N}\right)\right]$ moiety is located near a 4 -fold rotoinversion axis, which results in formation of the coordination tetramer $\left[\mathrm{K}(\text { diglyme })\left(\mathrm{C}_{16} \mathrm{H}_{12} \mathrm{~N}\right)\right]_{4}$ (Fig. 5 and S37 in the ESI $\dagger$ ) displaying the rare $S_{4}$ Schoenflies point group in a crystal structure. All four $\mathrm{K}^{+}$cations are located nearly but not quite in the same plane, with the $\mathrm{K} 1^{\mathrm{i}}-\mathrm{K} 1-\mathrm{K} 1^{\mathrm{ii}}$ angle of $89.65^{\circ}$ [symmetry code: (ii) $-y+3 / 2, x,-z+1 / 2]$. The tetramer forms layers parallel to the $a b$ plane (Fig. S38 in the ESI $\dagger$ ). Packing of two such layers parallel to the $a c$ plane is shown in Fig. S39 in the ESI. $\dagger$ A direct analogy can be traced between 7 and the previously described potassium fluorenide, which forms a trimeric solvate with diglyme (3-fold rotoinversion axis). ${ }^{40}$

Hence, a small change in the anion geometry (and consequently in its electronic structure), namely, altering the position of the $\mathrm{CH}_{\mathrm{Cp}}$ (or $\mathrm{NCH}_{3}$ ) fragment, results in dramatic structural changes and formation of either the 1D coordination polymer 6 or the tetramer 7 .

Potassium 11-phenyl-6H-indeno[1,2-b]indolizinide. Unlike all other compounds (5-7), salt 8 demonstrates a molecular structure in which $\mathrm{K}^{+}$is coordinated with the 11-phenyl-6Hindeno[1,2- $b]$ indolizinide anion, one diglyme and one THF

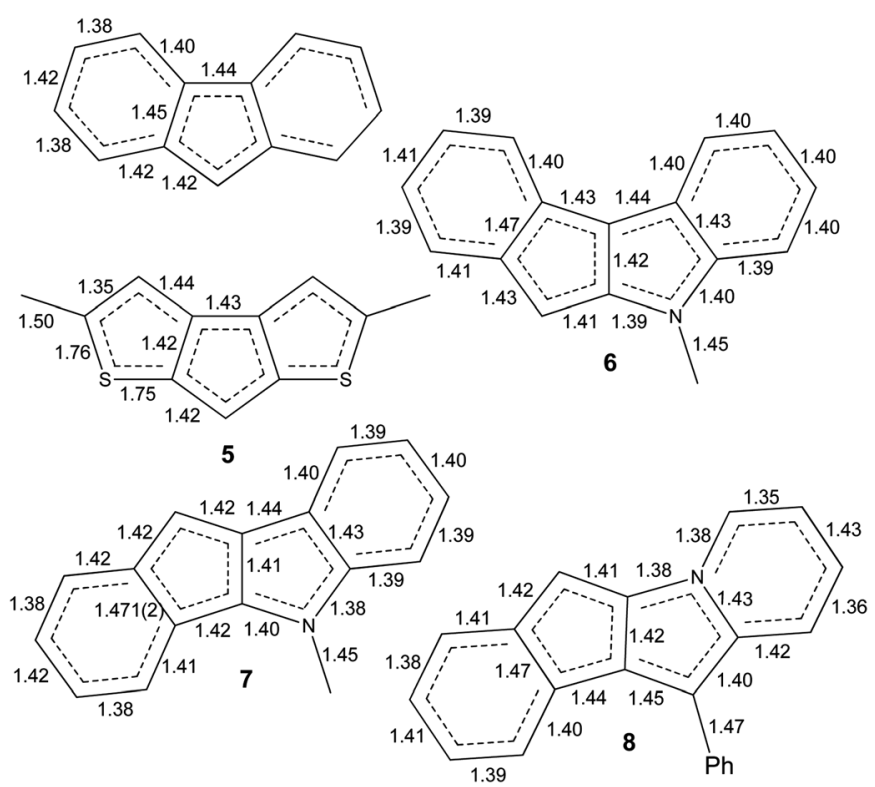

Scheme 5 The $\mathrm{C}-\mathrm{C}, \mathrm{C}-\mathrm{S}$ and $\mathrm{C}-\mathrm{N}$ bond distances in fluorenide anion $\left(\left(\mathrm{C}_{13} \mathrm{H}_{9}\right) \mathrm{K}(\text { diglyme })^{40}\right)$ and in anions of $5-8$. 
Table 2 Selected distances $(\AA)$ in $5^{a}$

\begin{tabular}{|c|c|c|c|}
\hline $\mathrm{K} 1-\mathrm{O} 1$ & $2.7543(17)$ & $\mathrm{K} 2-\mathrm{O} 1$ & $2.7998(17)$ \\
\hline $\mathrm{K} 1-\mathrm{O} 2$ & $2.8042(18)$ & $\mathrm{K} 2-\mathrm{O} 2$ & $2.9013(18)$ \\
\hline $\mathrm{K} 1-\mathrm{S} 2$ & $3.7814(8)$ & $\mathrm{K} 2-\mathrm{S} 4$ & $3.6343(8)$ \\
\hline $\mathrm{K} 1-\mathrm{C} 1$ & $3.173(2)$ & $\mathrm{K} 2-\mathrm{C} 12$ & $3.434(2)$ \\
\hline $\mathrm{K} 1-\mathrm{C} 3$ & $2.989(2)$ & $\mathrm{K} 2-\mathrm{C} 14$ & $2.976(2)$ \\
\hline $\mathrm{K} 1-\mathrm{C} 4$ & $3.300(2)$ & K2-C15 & $2.907(2)$ \\
\hline K1-C5 & $3.425(2)$ & K2-C16 & $3.214(2)$ \\
\hline $\mathrm{K} 1-\mathrm{C} 14^{\mathrm{i}}$ & $3.162(2)$ & $\mathrm{K} 2-\mathrm{C} 3^{\mathrm{ii}}$ & $3.142(2)$ \\
\hline $\mathrm{K} 1-\mathrm{C} 15^{\mathrm{i}}$ & $3.084(2)$ & $\mathrm{K} 2-\mathrm{C} 4^{\mathrm{ii}}$ & $3.290(2)$ \\
\hline \multirow[t]{2}{*}{$\mathrm{K} 1-\mathrm{C} 16^{\mathrm{i}}$} & $3.043(2)$ & $\mathrm{K} 2-\mathrm{C} 5^{\mathrm{ii}}$ & $3.197(2)$ \\
\hline & & K2-C19 & $3.353(2)$ \\
\hline K1-centroid C1 $\cdots$ C5 & $2.8526(13)$ & K2-centroid $\mathrm{C} 1^{\mathrm{ii}} \cdots \mathrm{C} 5^{\mathrm{ii}}$ & $2.8882(11)$ \\
\hline K1-centroid C12 ${ }^{\mathrm{i}} \cdots \mathrm{C} 16^{\mathrm{i}}$ & $2.8790(12)$ & K2-centroid C12 $\cdots \mathrm{C} 16$ & $2.9405(11)$ \\
\hline
\end{tabular}

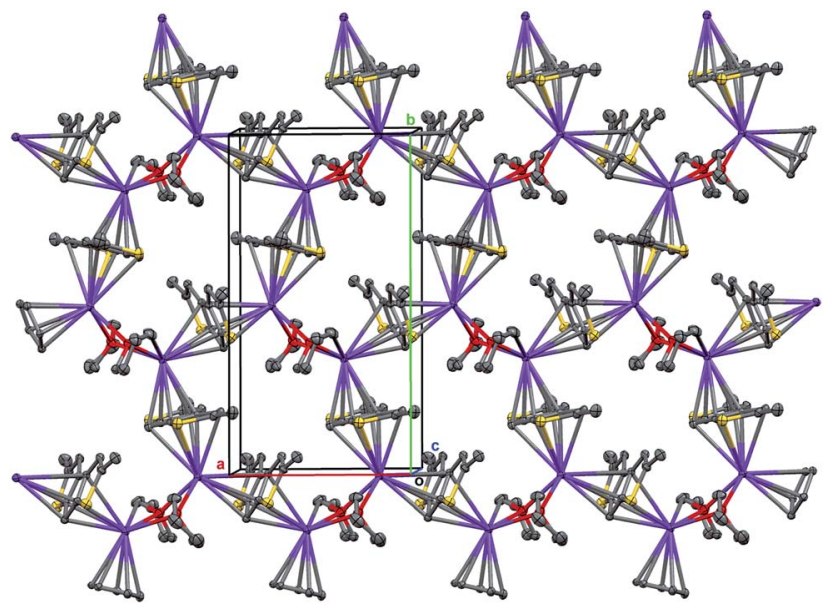

Fig. 2 A 2D coordination polymer sheet of 5, formed parallel to the ab plane. Displacement ellipsoids are set to the $50 \%$ probability level, $\mathrm{H}$ atoms are omitted.

molecule, [K(diglyme- $\left.\left.\kappa^{3} \mathrm{O}, \mathrm{O}^{\prime}, \mathrm{O}^{\prime \prime}\right)(\mathrm{THF}-\kappa \mathrm{O})\left(\eta^{5}-\mathrm{C}_{21} \mathrm{H}_{14} \mathrm{~N}\right)\right]$ (Fig. 5). The $\eta^{5}$-coordination mode of the anion is symmetrical: the $\mathrm{K}$ -

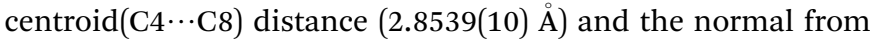
$\mathrm{K}$ to the $\mathrm{C} 4{ }^{\cdots} \mathrm{C} 8$ plane $(2.8287(10) \AA)$ are similar. The $\mathrm{K}-\mathrm{O}, \mathrm{K}-\mathrm{C}$ distances and bond lengths within the anion are given in Table
5 and in Scheme 5, correspondingly (other parameters are presented in Table S5 in the ESI $\dagger$ ). Due to steric hindrance, the phenyl group is rotated by $35.80(7)^{\circ}$ with respect to the nearly flat indeno[1,2- $b]$ indolizinide fragment. This indicates that the conjugation between $\mathrm{Ph}$ and $\mathrm{Cp}$ fragments is lost to a significant extent.

The $\left[\mathrm{K}\right.$ (diglyme)(THF) $\left.\left(\mathrm{C}_{21} \mathrm{H}_{14} \mathrm{~N}\right)\right]$ unit is sterically crowded enough not to form coordination polymers, yet the $\mathrm{K}^{+}$coordination sphere is insufficiently saturated, and $\mathrm{K}^{+}$has a low formal coordination number (7). Therefore, the anion $\left[\mathrm{C}_{21} \mathrm{H}_{14} \mathrm{~N}\right]^{-}$(atoms N1, C16, C15, C5, C6) and the cation $[\mathrm{K} \text { (diglyme)(THF) }]^{+}$of two different molecules, which are related by an inversion center, demonstrate weak electrostatic intermolecular interactions that lead to association into a dimeric unit (Fig. S41 in the ESI†े). Packing plots of 8, demonstrating the molecular lattice, are given in Fig. S42 and S43 in the ESI. $\dagger$

Comparison of the structures of heterocene-fused cyclopentadienides and potassium fluorenide. Potassium complex $\left(\mathrm{C}_{13} \mathrm{H}_{9}\right) \mathrm{K}(\text { diglyme })^{40}$ is the closest analog of 5-8. The analysis of the structures of heterocycle-fused cyclopentadienides allows us to conclude that the presence of annelated donor heterocycle instead of condensed benzene ring (Scheme 5) does not lead to significant changes in the geometry of $\mathrm{C} 5$ and $\mathrm{C} 6$ rings compared to fluorenide. Apparently, the possible causes of the difference observed in NMR spectra, and in the chemical

Table 3 Selected distances $(\AA)$ in $6^{a}$

\begin{tabular}{|c|c|c|c|}
\hline $\mathrm{K} 1-\mathrm{C} 2$ & $3.1916(12)$ & $\mathrm{K} 1-\mathrm{C} 8^{\mathrm{i}}$ & $3.2182(12)$ \\
\hline K1-C6 & $3.0119(13)$ & $\mathrm{K} 1-\mathrm{C} 12^{\mathrm{i}}$ & $3.5107(14)$ \\
\hline $\mathrm{K} 1-\mathrm{C} 7$ & $3.3135(13)$ & K1-O19 & $2.7784(10)$ \\
\hline $\mathrm{K} 1-\mathrm{C} 6^{\mathrm{i}}$ & $3.2869(13)$ & $\mathrm{K} 1-\mathrm{O} 22$ & $2.7611(9)$ \\
\hline K1-centroid C2, C6, C7 & $3.0115(8)$ & K1-normal N1, C1 $\cdots$ C17 & $2.9962(6)$ \\
\hline K1-centroid $C 6^{i}, C 7^{i}, C 8^{i}$ & $3.0071(7)$ & K1-normal N1 $1^{\mathrm{i}}, \mathrm{C} 1^{\mathrm{i}} \cdots \mathrm{C} 17^{\mathrm{i}}$ & $2.9841(5)$ \\
\hline
\end{tabular}

${ }^{a}$ Symmetry code: (i) $x,-y+1 / 2, z+1 / 2$. 

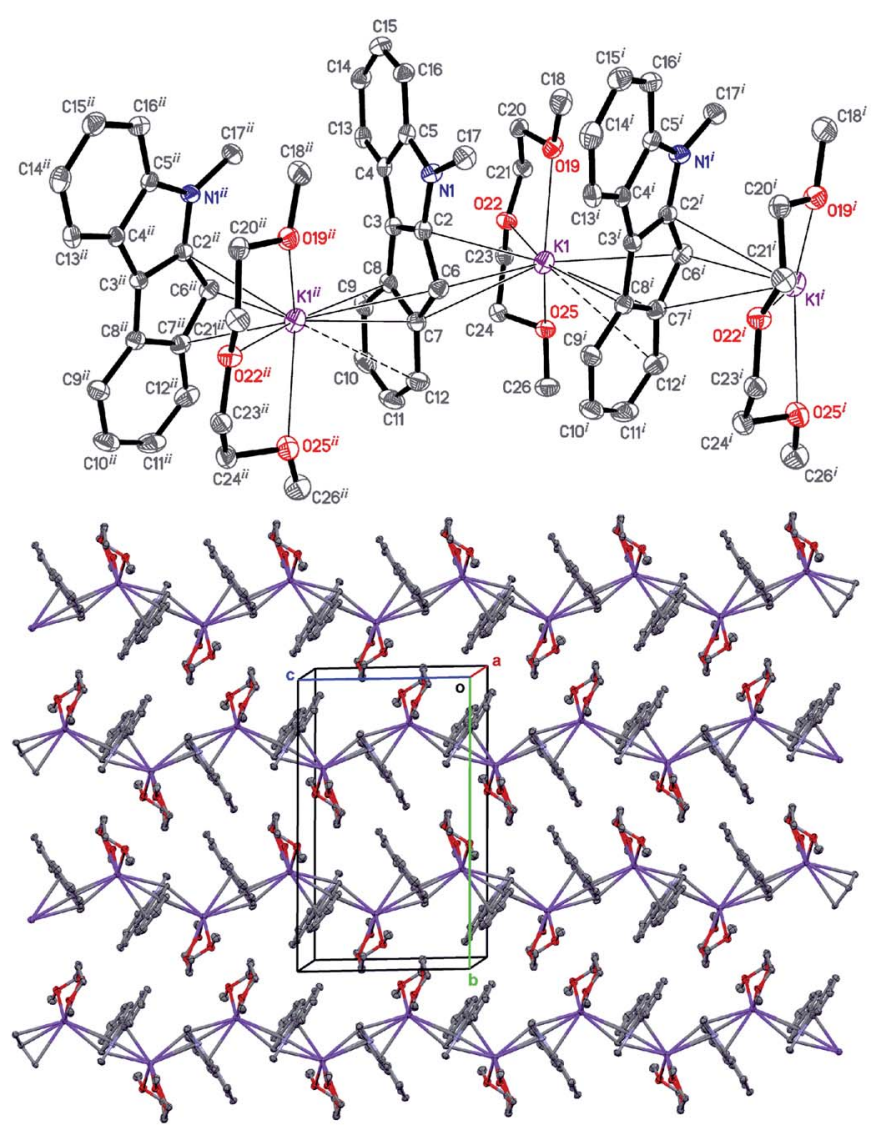

Fig. 3 The structure of $\left[K(\text { diglyme })\left(\mathrm{C}_{16} \mathrm{H}_{12} \mathrm{~N}\right)\right]_{\infty}$ (6) (top) and $1 \mathrm{D}$ coordination polymer chains of 6 , formed along the $c$ direction (bottom). Displacement ellipsoids are set to the $50 \%$ probability level, $\mathrm{H}$ atoms are omitted.

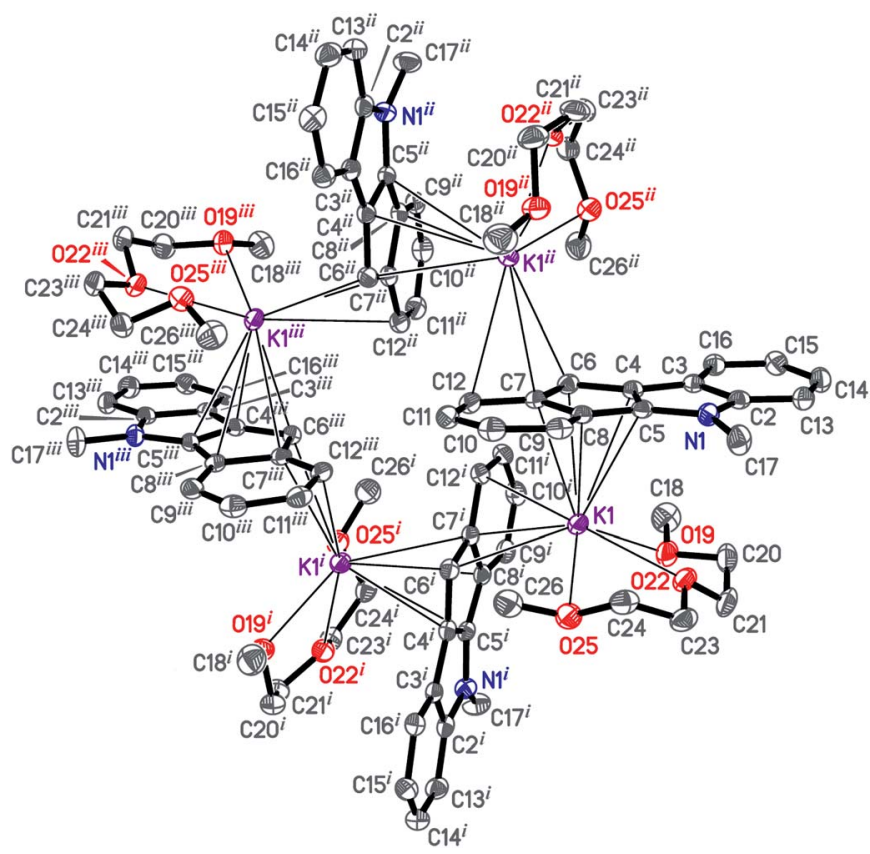

Fig. 4 The $\left[\mathrm{K} \text { (diglyme) }\left(\mathrm{C}_{16} \mathrm{H}_{12} \mathrm{~N}\right)\right]_{4}$ unit of 7. Displacement ellipsoids are drawn at the $50 \%$ probability level, $\mathrm{H}$ atoms are omitted for clarity.
Table 4 Selected bond lengths $(A)$ in 7

\begin{tabular}{llll}
\hline K1-C4 & $3.1508(14)$ & $\mathrm{K} 1-\mathrm{C} 7^{a}$ & $3.1300(14)$ \\
$\mathrm{K} 1-\mathrm{C} 5$ & $3.2627(13)$ & $\mathrm{K} 1-\mathrm{C} 12^{a}$ & $3.2972(15)$ \\
$\mathrm{K} 1-\mathrm{C} 6$ & $3.0442(14)$ & $\mathrm{K} 1-\mathrm{O} 19$ & $2.7295(12)$ \\
$\mathrm{K} 1-\mathrm{C} 7$ & $3.0866(13)$ & $\mathrm{K} 1-\mathrm{O} 22$ & $2.7170(10)$ \\
$\mathrm{K} 1-\mathrm{C} 8$ & $3.2825(14)$ & $\mathrm{K} 1-\mathrm{O} 25$ & $2.8313(12)$ \\
$\mathrm{K}^{2}-\mathrm{C} 6$ & \\
${ }^{a}$ Symmetry code: & $3.1131(14)$ & &
\end{tabular}

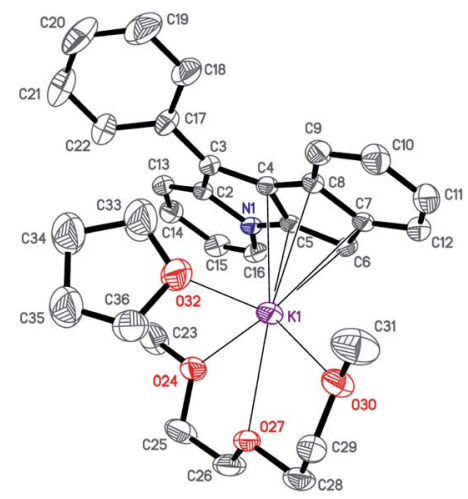

Fig. 5 The structure of $\left[\mathrm{K}\left(\right.\right.$ diglyme) $\left.(\mathrm{THF})\left(\mathrm{C}_{21} \mathrm{H}_{14} \mathrm{~N}\right)\right]$ (8). Displacement ellipsoids are drawn at the $50 \%$ probability level. All $\mathrm{H}$ atoms are omitted for clarity, minor disorder components are not shown.

behavior of zirconium complexes based on fluorene and $5-7,{ }^{17}$ can be attributed to the difference in the electronic structure of these ligands.

\section{DFT calculations}

Taking into account the results of NMR studies of compounds 5-8, which indicate significant shielding of the $\mathrm{C}(\mathrm{H})$ carbon atom in the $\mathrm{C}_{5}$ ring, we calculated the electronic structure of the corresponding anions at the PBE0/def-2-TZVP level of theory. ${ }^{41}$ Additionally, we estimated the influence of the potassium cation on the view and energy of orbitals by DFT optimization of model complex $\left[\mathrm{K}\left(\mathrm{Me}_{2} \mathrm{O}\right) \text { (diglyme) }\right]^{+}\left[\mathrm{C}_{16} \mathrm{H}_{12} \mathrm{~N}\right]^{-}$and found that such influence is negligible (see Fig. S44 in the ESI + ).

The plots for highest occupied molecular orbitals (HOMO) and lowest unoccupied molecular orbitals (LUMO) are presented in Fig. 6 . The atoms of $\mathrm{C}_{5}$-rings provide substantive input to the formation of HOMO for all heterocycle-fused cyclopentadienides, which affects the stabilization of metal cation in catalytic center. High symmetry in HOMO and LUMO in $\mathbf{5}$ explains the extremely high stability and catalytic productivity

Table 5 Selected bond lengths $(\AA)$ in 8

\begin{tabular}{llll}
\hline K1-C4 & $3.1598(19)$ & K1-O24 & $2.7209(17)$ \\
K1-C5 & $3.2236(19)$ & K1-O27 & $2.7374(17)$ \\
K1-C6 & $3.156(2)$ & K1-O30 & $2.7342(18)$ \\
K1-C7 & $2.9824(19)$ & K1-O32 & $2.686(4)$ \\
K1-C8 & $2.9827(19)$ & &
\end{tabular}


of cationic $\mathrm{Zr}$ complexes based on derivatives of cyclopenta[1,2$\left.b: 4,3-b^{\prime}\right]$ dithiophene. In addition, the impact of HOMO on $\pi$ electron density at the $\mathrm{C}(\mathrm{H})$ carbon atom in $\mathbf{5}$ is minimal, which correlates with the maximal chemical shift for this atom in the ${ }^{13} \mathrm{C}$ NMR spectrum of 5 . Substantial contribution of electrons at the $\mathrm{N}$ atom in 7 to HOMO allows us to assume the possibility of coordination of electrophiles at this atom in reactions catalyzed by indeno[ $[1,2-b]$ indolyl metal complexes; this significant aspect of catalytic behavior of these compounds is being explored in our laboratory.

\section{Experimental}

\section{General experimental remarks}

Materials and methods. All synthetic manipulations were performed in a purified argon atmosphere or under vacuum using an argon-filled glove box, standard Schlenk glassware or vacuum line techniques. $n$-Pentane, $n$-hexane and $n$-heptane (Merck, NJ, USA) were stored over Na and distilled under argon. Diethyl ether, THF, diethylene glycol dimethyl ether and toluene were refluxed over $\mathrm{Na} /$ benzophenone and distilled under argon. $\mathrm{CH}_{2} \mathrm{Cl}_{2}$ was refluxed over $\mathrm{CaH}_{2}$ and distilled.
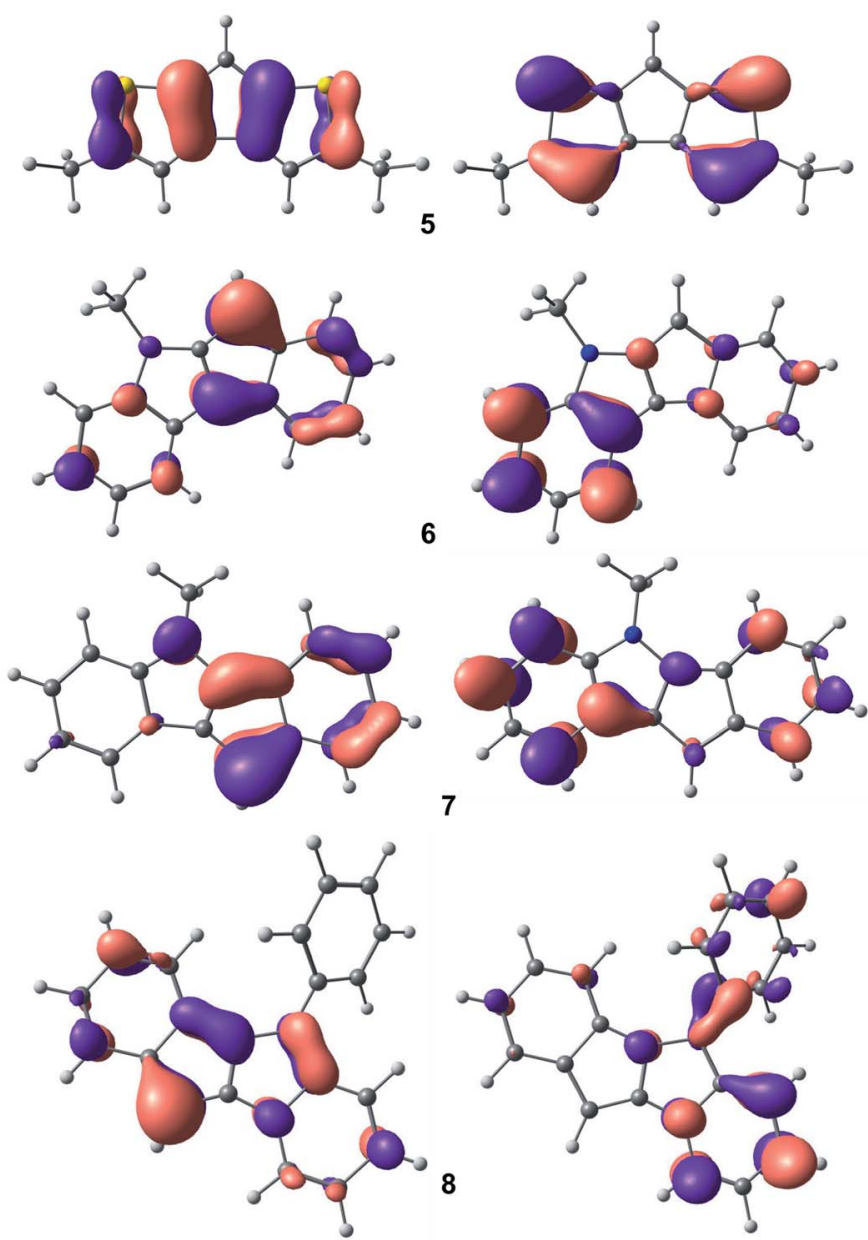

Fig. 6 HOMO (left) and LUMO (right) plots for anions 5-8 (PBEO/def2-TZVP).
Phenylhydrazine, 2,3-dihydro- $1 H$-inden-1-one (1-indanone), $1 H^{-}$ inden-2(3H)-one (2-indanone), thiophene-2-carbaldehyde, ethyl dimethylcarbamate, 2-benzylpyridine, (1,3-dppp) $\mathrm{NiCl}_{2}, \mathrm{AlCl}_{3}$, ${ }^{t} \mathrm{BuOK}, n$-BuLi (2.5 M solution in hexanes) and potassium tertpentoxide [potassium (2-methyl-2-butoxide), $\sim 1.7 \mathrm{M}$ solution in toluene] were used as purchased (Merck, NJ, USA). Benzyl potassium (or BnK) was prepared similarly to the published procedure. ${ }^{42}$

Analysis. $\mathrm{CDCl}_{3}$ (Cambridge Isotope Laboratories, Inc., D $99.8 \%$ ) was used as purchased. THF- $\mathrm{d}_{8}$ was stored over $\mathrm{Na} /$ tetraphenylethylene and condensed into NMR tubes. The ${ }^{1} \mathrm{H}$ and ${ }^{13} \mathrm{C}$ NMR spectra were recorded on Bruker AV400 $(400 \mathrm{MHz}$ for ${ }^{1} \mathrm{H}$ and $100.6 \mathrm{MHz}$ for $\left.{ }^{13} \mathrm{C}\right)$ or Bruker AV-600 $\left(600 \mathrm{MHz}\right.$ for ${ }^{1} \mathrm{H}$ and $150.9 \mathrm{MHz}$ for ${ }^{13} \mathrm{C}$ ) spectrometers at $20{ }^{\circ} \mathrm{C}$. The chemical shifts are reported in ppm relative to the solvent residual peaks. Elemental analysis $(\mathrm{C}, \mathrm{H}, \mathrm{N}, \mathrm{O})$ of heterocycle-fused cyclopentadienes was performed on a PerkinElmer Series II CHNS/O Analyzer 2400.

\section{Preparation of heterocycle-fused cyclopentadienes}

Optimized synthetic protocols and NMR spectra of compounds 1-3 are given in Section S1 in the ESI. $\dagger$ Indolizine derivative 4 was prepared as described below.

A solution of 2-benzylpyridine ( $16.9 \mathrm{~g}, 0.1 \mathrm{~mol})$ in acetone (50 $\mathrm{mL}$ ) was added to the solution of 2-bromo-2,3-dihydro- $1 \mathrm{H}^{-}$ inden-1-one $(21.1 \mathrm{~g}, 0.1 \mathrm{~mol})$ in acetone $(100 \mathrm{~mL})$ at $0{ }^{\circ} \mathrm{C}$. The mixture was allowed to warm to room temperature and was stirred for $12 \mathrm{~h}$. Acyl pyridinium bromide was filtered off, washed by hexane, dried, and transferred into a $500 \mathrm{~mL}$ flask containing $\mathrm{K}_{2} \mathrm{CO}_{3}(30 \mathrm{~g},>0.2 \mathrm{~mol})$ in water $(200 \mathrm{~mL})$. The mixture was stirred for $8 \mathrm{~h}$ at $80^{\circ} \mathrm{C}$ and cooled. The product was filtered off, recrystallized from EtOH and dried in vacuo. The yield of 4 was $17.4 \mathrm{~g}(62 \%)$, beige crystalline powder. Calculated for $\mathrm{C}_{21} \mathrm{H}_{15} \mathrm{~N}$ : C, 89.65; H, 5.37; N, 4.98. Found: C, 89.61; H, 5.44; N, 4.95. ${ }^{1} \mathrm{H}$ NMR $\left(293 \mathrm{~K}, 400 \mathrm{MHz}, \mathrm{CDCl}_{3}\right) \delta: 3.78$ (bs, $2 \mathrm{H}$, $\left.-\mathrm{CH}_{2}-\right), 6.56\left(\mathrm{t}, 1 \mathrm{H},{ }^{3} J_{\mathrm{HH}}=6.9 \mathrm{~Hz}\right), 6.68(\mathrm{~m}, 1 \mathrm{H}), 7.21\left(\mathrm{t}, 1 \mathrm{H},{ }^{3} J_{\mathrm{HH}}\right.$ $=6.9 \mathrm{~Hz}), 7.29\left(\mathrm{t}, 1 \mathrm{H},{ }^{3} J_{\mathrm{HH}}=7.5 \mathrm{~Hz}\right), 7.37\left(\mathrm{t}, 1 \mathrm{H}, \mathrm{CH}_{\mathrm{Ar}},{ }^{3} J_{\mathrm{HH}}=\right.$ $7.4 \mathrm{~Hz}), 7.49\left(\mathrm{~d}, 1 \mathrm{H}, \mathrm{CH}_{\mathrm{Ar}},{ }^{3} J_{\mathrm{HH}}=7.4 \mathrm{~Hz}\right), 7.55\left(\mathrm{t}, 1 \mathrm{H}, \mathrm{CH}_{\mathrm{Ar}},{ }^{3} J_{\mathrm{HH}}\right.$ $=7.9 \mathrm{~Hz}), 7.67\left(\mathrm{~d}, 1 \mathrm{H}, \mathrm{CH}_{\mathrm{Ar}},{ }^{3} \mathrm{~J}_{\mathrm{HH}}=8.1 \mathrm{~Hz}\right), 7.76(\mathrm{~m}, 4 \mathrm{H}) .{ }^{13} \mathrm{C}$ $\left\{{ }^{1} \mathrm{H}\right\}$ NMR $\left(293 \mathrm{~K}, 101 \mathrm{MHz}, \mathrm{CDCl}_{3}\right) \delta: 29.38,106.03,108.31$, 111.11, 116.50, 118.83, 120.61, 122.55, 124.69, 125.34, 125.81, 126.91, 128.44, 128.78, 129.12, 130.54, 131.18, 133.84, 135.73, 139.19, 144.26 (see Fig. S1 and S2 in the ESI $\dagger$ ).

\section{Synthesis of potassium salts}

Synthesis and crystallization of 5 . A solution of BnK $(68 \mathrm{mg}$, $0.53 \mathrm{mmol}$ ) in THF ( $5 \mathrm{~mL}$ ) was added to a stirred solution of 1 $(103 \mathrm{mg}, 0.50 \mathrm{mmol})$ in THF $(10 \mathrm{~mL})$. After $30 \mathrm{~min}$, the mixture was evaporated to $\sim 7-8 \mathrm{~mL}$ of the residual volume, and hexane (30 mL) was carefully layered on top. After one week, yellow crystals of $\mathbf{5}$ were separated by decantation and dried under vacuum. The yield of 5 was $123 \mathrm{mg}(0.39 \mathrm{mmol}, 78 \%) .{ }^{1} \mathrm{H}$ NMR $\left(303 \mathrm{~K}, 600 \mathrm{MHz}, \mathrm{THF}-\mathrm{d}_{8}\right) \delta: 1.76-1.80\left(\mathrm{~m},-\mathrm{CH}_{2}-\mathrm{CH}_{2}-\mathrm{O}-\right), 2.43$ (s, $\left.6 \mathrm{H},-\mathrm{CH}_{3},{ }^{1} J_{\mathrm{CH}}=126.5 \mathrm{~Hz}\right), 3.60-3.64\left(\mathrm{~m},-\mathrm{CH}_{2}-\mathrm{CH}_{2}-\mathrm{O}-\right.$ ), $5.64\left(\mathrm{~s}, 1 \mathrm{H}, \mathrm{CH}_{\mathrm{Ar}},{ }^{1} J_{\mathrm{CH}}=168.5 \mathrm{~Hz}\right), 6.58\left(\mathrm{~s}, 2 \mathrm{H}, \mathrm{CH}_{\mathrm{Ar}},{ }^{1} J_{\mathrm{CH}}=\right.$ $157.5 \mathrm{~Hz}) .{ }^{13} \mathrm{C}\left\{{ }^{1} \mathrm{H}\right\}$ NMR $\left(303 \mathrm{~K}, 150 \mathrm{MHz}, \mathrm{THF}-\mathrm{d}_{8}\right) \delta: 17.03$ 
$\left(-\mathrm{CH}_{3}\right), 26.55\left(-\mathrm{CH}_{2}-\mathrm{CH}_{2}-\mathrm{O}-\right), 68.39\left(-\mathrm{CH}_{2}-\mathrm{CH}_{2}-\mathrm{O}-\right), 82.44$ $\left(\mathrm{CH}_{\mathrm{Ar}}\right), 116.66\left(\mathrm{CH}_{\mathrm{Ar}}\right), 119.40,123.75,126.56$ (see Fig. S3-S6 ${ }^{1} \mathrm{H}$, ${ }^{13} \mathrm{C}\left\{{ }^{1} \mathrm{H}\right\},{ }^{1} \mathrm{H}-{ }^{13} \mathrm{C}$ HSQC and ${ }^{1} \mathrm{H}-{ }^{13} \mathrm{C}$ HMBC NMR spectra in the ESI $\dagger$ ).

Synthesis and crystallization of 6. A solution of BnK (66 mg, $0.51 \mathrm{mmol})$ in THF ( $5 \mathrm{~mL}$ ) was added to a stirred solution of 2 $(110 \mathrm{mg}, 0.50 \mathrm{mmol})$ in THF $(10 \mathrm{~mL})$. After $30 \mathrm{~min}$, the mixture was evaporated to $\sim 7-8 \mathrm{~mL}$ of the residual volume, and diglyme (3 mL) was added. After $15 \mathrm{~min}$, hexane $(30 \mathrm{~mL})$ was layered on top. After one week, colorless crystals of $\mathbf{6}$ were separated by decantation and dried under vacuum. The yield of 6 was $158 \mathrm{mg}$ (0.40 mmol, 81\%). ${ }^{1} \mathrm{H}$ NMR (303 K, $600 \mathrm{MHz}$, THF-d $\left.{ }_{8}\right) \delta: 3.16$ (s, $\left.6 \mathrm{H},-\mathrm{OCH}_{3}\right), 3.29\left(\mathrm{t}, 4 \mathrm{H}, \mathrm{CH}_{3} \mathrm{OCH}_{2} \mathrm{CH}_{2}\right), 3.35\left(\mathrm{t}, 4 \mathrm{H}, \mathrm{CH}_{3}-\right.$ $\left.\mathrm{OCH}_{2} \mathrm{CH}_{2}\right), 3.64\left(\mathrm{~s}, \mathrm{~N}-\mathrm{CH}_{3}\right), 5.51\left(\mathrm{~s}, 1 \mathrm{H}, \mathrm{CH}_{\mathrm{Cp}}\right), 6.53(\mathrm{t}, 1 \mathrm{H}), 6.59$ $(\mathrm{t}, 1 \mathrm{H}), 6.72(\mathrm{t}, 1 \mathrm{H}), 6.83(\mathrm{t}, 1 \mathrm{H}), 6.96\left(\mathrm{~d}, 1 \mathrm{H},{ }^{3} J_{\mathrm{HH}}=7.7 \mathrm{~Hz}\right), 7.28$ $\left(\mathrm{d}, 1 \mathrm{H},{ }^{3} J_{\mathrm{HH}}=7.8 \mathrm{~Hz}\right), 7.47\left(\mathrm{~d}, 1 \mathrm{H},{ }^{3} \mathrm{~J}_{\mathrm{HH}}=7.5 \mathrm{~Hz}\right), 7.59(\mathrm{~d}, 1 \mathrm{H}$, $\left.{ }^{3} J_{\mathrm{HH}}=7.6 \mathrm{~Hz}\right) \cdot{ }^{13} \mathrm{C}\left\{{ }^{1} \mathrm{H}\right\} \mathrm{NMR}\left(303 \mathrm{~K}, 150 \mathrm{MHz}, \mathrm{THF}-\mathrm{d}_{8}\right) \delta: 31.12$ $\left(\mathrm{NCH}_{3}\right), 58.97\left(\mathrm{OCH}_{3}\right), 69.28\left(\mathrm{CH}_{\mathrm{Cp}}\right), 71.05\left(\mathrm{OCH}_{2} \mathrm{CH}_{2} \mathrm{OCH}_{3}\right)$, $72.72\left(\mathrm{OCH}_{2} \mathrm{CH}_{2} \mathrm{OCH}_{3}\right), 101.88,106.21,111.41,114.38,115.30$, 115.58, 116.98, 117.21, 117.59, 120.67, 127.10, 136.60, 143.86, 149.60 (see Fig. S7-S13 in the ESI $\uparrow$ for ${ }^{1} \mathrm{H},{ }^{13} \mathrm{C}\left\{{ }^{1} \mathrm{H}\right\},{ }^{1} \mathrm{H}-{ }^{1} \mathrm{H}$ COSY and ROESY, ${ }^{1} \mathrm{H}-{ }^{13} \mathrm{C}$ HSQC, ${ }^{1} \mathrm{H}^{1}{ }^{13} \mathrm{C}$ HMBC NMR spectra).

Synthesis and crystallization of 7 . The synthesis and crystallization of 7 was accomplished from $3(110 \mathrm{mg}, 0.50 \mathrm{mmol})$ by the method described above for 6 . The yield of red crystals of 7 was $149 \mathrm{mg}$ (0.38 mmol, 76\%). ${ }^{1} \mathrm{H}$ NMR (303 K, $600 \mathrm{MHz}$, THF$\left.\mathrm{d}_{8}\right) \delta: 3.13\left(\mathrm{~s}, 6 \mathrm{H},-\mathrm{OCH}_{3}\right), 3.25\left(\mathrm{t}, 4 \mathrm{H}, \mathrm{CH}_{3} \mathrm{OCH}_{2} \mathrm{CH}_{2}\right), 3.30(\mathrm{t}$, $\left.4 \mathrm{H}, \mathrm{CH}_{3} \mathrm{OCH}_{2} \mathrm{CH}_{2}\right), 3.98\left(\mathrm{~s}, \mathrm{~N}-\mathrm{CH}_{3}\right), 5.92\left(\mathrm{~s}, 1 \mathrm{H}, \mathrm{CH}_{\mathrm{Cp}}\right), 6.31(\mathrm{t}$, $1 \mathrm{H}), 6.45(\mathrm{t}, 1 \mathrm{H}), 6.83(\mathrm{t}, 1 \mathrm{H}), 6.97(\mathrm{t}, 1 \mathrm{H}), 7.14\left(\mathrm{~d}, 1 \mathrm{H},{ }^{3} J_{\mathrm{HH}} 8.0\right.$ $\mathrm{Hz}), 7.28\left(\mathrm{~d}, 1 \mathrm{H},{ }^{3} J_{\mathrm{HH}}=8.2 \mathrm{~Hz}\right), 7.63\left(\mathrm{~d}, 1 \mathrm{H},{ }^{3} J_{\mathrm{HH}}=7.2 \mathrm{~Hz}\right), 7.64$ $\left(\mathrm{d}, 1 \mathrm{H},{ }^{3} J_{\mathrm{HH}}=7.8 \mathrm{~Hz}\right) \cdot{ }^{13} \mathrm{C}\left\{{ }^{1} \mathrm{H}\right\} \mathrm{NMR}\left(303 \mathrm{~K}, 150 \mathrm{MHz}, \mathrm{THF}-\mathrm{d}_{8}\right) \delta$ : $32.42\left(\mathrm{NCH}_{3}\right), 58.94\left(\mathrm{OCH}_{3}\right), 70.98\left(\mathrm{OCH}_{2} \mathrm{CH}_{2} \mathrm{OCH}_{3}\right), 72.66$ $\left(\mathrm{OCH}_{2} \mathrm{CH}_{2} \mathrm{OCH}_{3}\right), 75.92\left(\mathrm{CH}_{\mathrm{Cp}}\right), 107.58,108.83,109.48,114.28$, 115.91 , 116.82, 119.26, 119.58, 121.74, 124.09, 127.54, 132.62, 144.68 (see Fig. S14-S20 in the ESI $\dagger$ for ${ }^{1} \mathrm{H},{ }^{13} \mathrm{C}\left\{{ }^{1} \mathrm{H}\right\},{ }^{1} \mathrm{H}-{ }^{1} \mathrm{H}$ COSY and ROESY, ${ }^{1} \mathrm{H}_{-}{ }^{13} \mathrm{C}$ HSQC,${ }^{1} \mathrm{H}-{ }^{13} \mathrm{C}$ HMBC NMR spectra).

Synthesis and crystallization of 8 . The synthesis and crystallization of $\mathbf{8}$ were carried out as described above for $\mathbf{6}$, instead using 11-phenyl-6H-indeno[1,2-b]indolizine 4 (141 mg, 0.5 $\mathrm{mmol}$ ) as a starting compound. The yield of dark red crystals was $210 \mathrm{mg}$ (0.40 mmol, 80\%). ${ }^{1} \mathrm{H}$ NMR (303 K, $600 \mathrm{MHz}$, THF$\left.\mathrm{d}_{8}\right) \delta: 3.06\left(\mathrm{~s}, 6 \mathrm{H},-\mathrm{OCH}_{3}\right), 3.16\left(\mathrm{t}, 4 \mathrm{H}, \mathrm{CH}_{3} \mathrm{OCH}_{2} \mathrm{CH}_{2}\right), 3.20(\mathrm{t}$, $\left.4 \mathrm{H}, \mathrm{CH}_{3} \mathrm{OCH}_{2} \mathrm{CH}_{2}\right), 5.88\left(\mathrm{~s}, 1 \mathrm{H}, \mathrm{CH}_{\mathrm{Cp}}\right), 6.17(\mathrm{t}, 1 \mathrm{H}), 6.31(\mathrm{dd}, 1 \mathrm{H}$, $\left.{ }^{3} J_{\mathrm{HH}}=9.1 \mathrm{~Hz},{ }^{3} J_{\mathrm{HH}}=6.1 \mathrm{~Hz}\right), 6.39(\mathrm{t}, 1 \mathrm{H}), 6.71(\mathrm{t}, 1 \mathrm{H}), 7.08(\mathrm{t}$, $1 \mathrm{H}), 7.37(\mathrm{~d}, 1 \mathrm{H}), 7.39(\mathrm{t}, 2 \mathrm{H}), 7.62\left(\mathrm{~d}, 1 \mathrm{H},{ }^{3} J_{\mathrm{HH}}=9.2 \mathrm{~Hz}\right), 7.86(\mathrm{~d}$, $\left.1 \mathrm{H},{ }^{3} \mathrm{~J}_{\mathrm{HH}}=6.9 \mathrm{~Hz}\right), 6.91$ (br. d, $\left.3 \mathrm{H}\right) .{ }^{13} \mathrm{C}\left\{{ }^{1} \mathrm{H}\right\} \operatorname{NMR}(303 \mathrm{~K}, 150$ MHz, THF-d 8 ) $\delta: 58.88\left(\mathrm{OCH}_{3}\right), 67.61\left(\mathrm{CH}_{\mathrm{Cp}}\right), 70.72\left(\mathrm{OCH}_{2} \mathrm{CH}_{2}-\right.$ $\left.\mathrm{OCH}_{3}\right), 72.48\left(\mathrm{OCH}_{2} \mathrm{CH}_{2} \mathrm{OCH}_{3}\right), 105.78,106.00,108.61,112.88$, $113.34,115.73,116.94,117,118.62,120.24,123.76,124.78$, $128.85,129.14,129.50,136.46,136.89,140.75\left(\mathrm{C}_{\text {ipso }} \mathrm{Ph}\right)$ (see Fig. S21-S26 in the ESI $\dagger$ for ${ }^{1} \mathrm{H},{ }^{13} \mathrm{C}\left\{{ }^{1} \mathrm{H}\right\},{ }^{1} \mathrm{H}-{ }^{1} \mathrm{H}$ COSY and ROESY, ${ }^{1} \mathrm{H}-{ }^{13} \mathrm{C}$ HSQC and HMBC NMR spectra).

\section{Crystallography}

The experimental intensities of single crystal reflections were measured on a Bruker SMART APEX II platform at $120 \mathrm{~K}$, using graphite monochromatized Mo-K $\alpha$ radiation $(\lambda=0.71073 \AA)$ in $\omega$-scan mode. The collected data were integrated with the SAINT program. ${ }^{43}$ Absorption corrections based on measurements of equivalent reflections were carried out by SADABS. ${ }^{44}$ The structures were solved by direct methods with the SHELXS program $^{45}$ and refined by full matrix least-squares on $\mathrm{F}^{2}$ with SHELXL. ${ }^{46}$ Crystal data, data collection and structure refinement details are summarized in Table S1 in the ESI. $\dagger$ The positions of all non-hydrogen atoms were found from electron difference density maps. Non-hydrogen atoms were refined with individual anisotropic displacement parameters. Positions of all hydrogen atoms (with the exception of disordered THF fragments in $\mathbf{5}$ and 8) were also found from the difference map, but hydrogen atoms were positioned geometrically and refined as riding atoms with relative isotropic displacement parameters. The SHELXTL program suite ${ }^{47}$ and the Mercury program ${ }^{48}$ were used for molecular graphics. Selected bond distances and angles, as well as more detailed data refinement and crystal structure description, are presented in Section S2 in the ESI. $\dagger$ CCDC numbers are 1920202-1920205 for compounds 5-8, respectively. $\dagger$

\section{Quantum chemical calculations}

All quantum chemistry computations were performed with the Gaussian 09 program (Revision D.01) ${ }^{49}$ using density functional theory (PBE0) ${ }^{41}$ and the def-2-TZVP basis set. Topological analyses of the $\rho(r)$ function integration over interatomic zero-flux surfaces were performed using the AIMAll program. ${ }^{50}$ All expected critical points were found, and the whole set of critical points in each system satisfies the Poincaré-Hopf rule.

\section{Conclusions}

In the present paper, we report the results of comparative study of crystal, molecular and electronic structures of four potassium cyclopentadienides that contain $\mathrm{C}_{5}$ rings annelated with thiophene $(5)$, indole $(6,7)$ and indolizine $(\mathbf{8})$ fragments. Depending on the type of ligand, the metal atoms exhibit a wide range of coordination, from traditional $\eta^{5}$-Cp to allyl-like $\eta^{3}$ with involvement of carbon atoms of the benzene rings. The variety of coordination modes resulted in an amazing diversity in crystal packing. Potassium derivatives of four different ligands formed four different types of crystal packing, from de facto molecular crystal for indolizine derivative 8 via tetrameric association (indeno[1,2- $b]$ indolide salt 7 ) to one-dimensional (indeno[2,1-b]indolide complex 6) and two-dimensional (cyclopenta[1,2-b:4,3- $\left.b^{\prime}\right]$ dithiophenide 5) coordination polymers. These results are important for understanding the transmetallation mechanisms in the synthesis of sandwich metal complexes.

NMR spectra and results of DFT modeling allowed us to conclude that the presence of annelated electron-donor heterocyclic fragments increases the $\pi$-electron density in the $\mathrm{Cp}$ ring. This effect is enhanced for $\mathrm{N}$-containing ligands and maximal for indolizine derivative 8. Thus, the novel compound 11-phenyl-6H-indeno[1,2- $b]$ indolizine 4 , the synthesis of which 
was reported in this manuscript, represents a prospective ligand for the design of metallocene catalysts with potentially high thermal stability and excellent productivity in $\alpha$-olefin polymerization. The preparation and study of indeno[1,2- $b]$ indolizine complexes is now considered a promising area for our future research.

\section{Conflicts of interest}

There are no conflicts to declare.

\section{Acknowledgements}

This work was supported by Russian Science Foundation (Grant No. 18-13-00351). This work was carried out within the State Program of TIPS RAS in part of NMR study of 4-8.

\section{Notes and references}

1 M. Delferro and T. J. Marks, Chem. Rev., 2011, 111, 24502485.

2 R. Zhao, J. Ma, H. Zhang and J. Huang, Molecules, 2017, 22, 856.

3 M. Stürzel, S. Mihan and R. Mülhaupt, Chem. Rev., 2016, 116, 1398-1433.

4 L. Friebe, O. Nuyken and W. Obrecht, Adv. Polym. Sci., 2006, 204, 1-154.

5 S. A. Hauser, M. Cokoja and F. E. Kühn, Catal. Sci. Technol., 2013, 3, 552-561.

6 I. I. E. Markovits, M. H. Anthofer, H. Kolding, M. Cokoja, A. Pöthig, A. Raba, W. A. Herrmann, R. Fehrmann and F. E. Kühn, Catal. Sci. Technol., 2014, 4, 3845-3849.

7 M. Zaranek and P. Pawluc, ACS Catal., 2018, 8, 9865-9876. 8 Y. Nakayama and T. Shiono, Molecules, 2005, 10, 620-633.

9 M. E. Minyaev, A. A. Vinogradov, A. V. Churakov, B. Kimmich, I. E. Nifant'ev, S. M. Nagy and P. V. Ivchenko, Mendeleev Commun., 2018, 28, 508-510.

10 J. A. Ewen, M. J. Elder, R. L. Jones, A. L. Rheingold, L. M. Liable-Sands and R. D. Sommer, J. Am. Chem. Soc., 2001, 123, 4763-4773.

11 C. De Rosa, F. Auriemma, A. Di Capua, L. Resconi, S. Guidotti, I. Camurati, I. E. Nifant'ev and I. P. Laishevtsev, J. Am. Chem. Soc., 2004, 126, 17040-17049.

12 C. De Rosa, F. Auriemma and L. Resconi, Angew. Chem., Int. Ed., 2009, 48, 9871-9874.

13 S. H. Kim, J. H. Park, B. G. Song, S.-W. Yoon, M. J. Go, J. Lee and B. Y. Lee, Catalysts, 2013, 3, 104-124.

14 I. E. Nifant'ev, I. P. Laishevtsev, P. V. Ivchenko, I. A. Kashulin, S. Guidotti, F. Piemontesi, I. Camurati, L. Resconi, P. A. A. Klusener, J. J. H. Rijsemus, K. P. de Kloe and F. M. Korndorffer, Macromol. Chem. Phys., 2004, 205, 2275-2291.

15 L. Resconi, S. Guidotti, I. Camurati, R. Frabetti, F. Focante, I. E. Nifant'ev and I. P. Laishevtsev, Macromol. Chem. Phys, 2005, 206, 1405-1438.
16 I. E. Nifant'ev, A. A. Vinogradov, A. A. Vinogradov, I. V. Sedov, V. G. Dorokhov, A. S. Lyadov and P. V. Ivchenko, Appl. Catal., A, 2018, 549, 40-50.

17 I. E. Nifant'ev, A. A. Vinogradov, A. A. Vinogradov, A. V. Churakov, V. V. Bagrov, I. A. Kashulin, V. A. Roznyatovsky, Y. K. Grishin and P. V. Ivchenko, Appl. Catal., A, 2019, 571, 12-24.

18 I. E. Nifant'ev, L. Y. Ustynyuk and D. N. Laikov, Organometallics, 2001, 20, 5375-5393.

19 J. A. Ewen, R. L. Jones, M. J. Elder, A. L. Rheingold and L. M. Liable-Sands, J. Am. Chem. Soc., 1998, 120, 1078610787.

20 F. van Baar, A. D. Horton, K. P. de Kloe, E. Kragtwijk, S. G. Mkoyan, I. E. Nifant'ev, P. A. Schut and I. V. Taidakov, Organometallics, 2003, 22, 2711-2722.

21 S. Deisenhofer, T. Feifel, J. Kukral, M. Klinga, M. Leskelä and B. Rieger, Organometallics, 2003, 22, 3495-3501.

22 A. N. Ryabov, D. V. Gribkov, V. V. Izmer and A. Z. Voskoboynikov, Organometallics, 2002, 21, 2842-2855. 23 V. V. Izmer, A. Y. Lebedev, M. V. Nikulin, A. N. Ryabov, A. F. Asachenko, A. V. Lygin, D. A. Sorokin and A. Z. Voskoboynikov, Organometallics, 2006, 25, 1217-1229. 24 Z. M. Dzhabieva, S. V. Topilin, G. V. Shilov and T. S. Dzhabiev, Russ. J. Inorg. Chem., 2012, 57, 46-51.

25 I. E. Nifant'ev, A. A. Vinogradov, M. E. Minyaev, K. A. Lyssenko and P. V. Ivchenko, Mendeleev Commun., 2019, 29, 266-268.

26 R. Michel, R. Herbst-Irmer and D. Stalke, Organometallics, 2011, 30, 4379-4386.

27 G. Erker, G. Kehr and R. Fröhlich, Organometallics, 2008, 27, 3-14.

28 I. E. Nifant'ev, I. A. Kashulin, P. V. Ivchenko, P. A. Klusener, F. M. Korndorffer, K. P. De Kloe and J. J. H. Rijsemus, U.S. Pat. 7635781 (B2), 2009.

29 D. Brown, P. Graupner, M. Sainsbury and H. Shertzer, Tetrahedron, 1991, 47, 4383-4408.

30 I. E. Nifant'ev and V. V. Bagrov, U.S. Pat. 6451724 (B1), 2002. 31 R.-B. Hu, S. Sun and Y. Su, Angew. Chem., Int. Ed., 2017, 56, 10877-10880.

32 V. S. Venturella, J. Pharm. Sci., 1963, 52, 868-871.

33 M. E. Minyaev, A. A. Vinogradov, D. M. Roitershtein, R. S. Borisov, I. V. Ananyev, A. V. Churakov and I. E. Nifant'ev, J. Organomet. Chem., 2016, 818, 128-136.

34 D. M. Roitershtein, L. N. Puntus, A. A. Vinogradov, K. A. Lyssenko, M. E. Minyaev, M. D. Dobrokhodov, I. V. Taidakov, E. A. Varaksina, A. V. Churakov and I. E. Nifant'ev, Inorg. Chem., 2018, 57, 10199-10213.

35 J. E. Ellis, M. E. Minyaev, I. E. Nifant'ev and A. V. Churakov, Acta Crystallogr., Sect. C: Struct. Chem., 2018, 74, 769-781.

36 T. K. Panda, M. T. Gamer and P. W. Roesky, Organometallics, 2003, 22, 877-878.

37 T. Kinoshita, N. Murata, R. Fujita, Y. Yanagi and K. Takeuchi, J. Organomet. Chem., 1994, 471, 19-21.

38 R. E. Dinnebier, S. Neander, U. Behrens and F. Olbrich, Organometallics, 1999, 18, 2915-2918.

39 A. Zaeni, U. Behrens, P. Liebing, F. Olbrich and F. T. Edelmann, J. Organomet. Chem., 2017, 830, 141-145. 
40 S. Neander, J. Kornich and F. Olbrich, J. Organomet. Chem., 2002, 656, 89-96.

41 J. P. Perdew, M. Ernzerhof and K. Burke, J. Chem. Phys., 1996, 105, 9982-9985.

42 L. Lochmann and J. Trekoval, J. Organomet. Chem., 1987, 326, 1-7.

43 Bruker, APEX2, Bruker AXS Inc., Madison, Wisconsin, USA, 2008.

44 L. Krause, R. Herbst-Irmer, G. M. Sheldrick and D. Stalke, J. Appl. Crystallogr., 2015, 48, 3-10.

45 G. M. Sheldrick, Acta Crystallogr., Sect. A: Found. Crystallogr., 2008, 64, 112-122.

46 G. M. Sheldrick, Acta Crystallogr., Sect. C: Struct. Chem., 2015, 71, 3-8.
47 G. M. Sheldrick, Acta Crystallogr., Sect. A: Found. Adv., 2015, 71, 3-8.

48 C. F. Macrae, P. R. Edgington, P. McCabe, E. Pidcock, G. P. Shields, R. Taylor, M. Towler and J. van de Streek, J. Appl. Crystallogr., 2006, 39, 453-457.

49 D. J. F. M. Frisch, J. G. W. Trucks, H. B. Schlegel, G. E. Scuseria, M. A. Robb, J. R. Cheeseman, G. Scalmani, V. Barone, G. A. Petersson, H. Nakatsuji, X. Li, M. Caricato, A. Marenich, J. Bloino, B. G. Janesko, R. Gomperts, B. Mennucci, H. P. Hratchian and J. V. Ort, Gaussian 09, Revision D.01, Gaussian Inc., Wallingford CT, 2016. 50 T. Keith, AIMAll ver. 16.08.17. 